IVAN M. BECIĆ, naučni saradnik

UDK 336.02(497.1)"1936/1939"

Medicinska škola

32:929 Стојадиновић М.

Leskovac, Bore Dimitrijevića Piksle 1

\title{
FINANSIJSKA POLITIKA MILANA STOJADINOVIĆA
}

\begin{abstract}
APSTRAKT: U jugoslovenskoj istoriografiji ličnost Milana Stojadinovića prvenstveno je izučavana kao faktor spoljne politike Kraljevine Jugoslavije u drugoj polovini tridesetih godina XX veka. Njegova angažovanost u sređivanju državnih finansija najčešće je uzgred pominjana, a mišljenje o njegovim rezultatima je podeljeno. U članku su analizirana Stojadinovićeva postignuća na ovom polju, čime su predstavljeni i činioci koji su odlučivali o pravcu državne finansijske politike.
\end{abstract}

Ključne reči: inflacija, deflacija, Milan Stojadinović, budžet, finansije, Narodna banka

Milan Stojadinović je pripadao najmlađoj generaciji političara koji su se pojavili na političkoj sceni Kraljevine SHS u trenucima kada je ova država stvorena. Koristeći sistem obrazovanja i mogućnosti koje je pružao na razmeđu XIX i XX veka, Stojadinović se posle završenog pravnog fakulteta posvetio ekonomiji i sa 23 godine doktorirao sa tezom „Nemački budžet“. Kao perspektivnog stručnjaka prepoznali su ga Stojan Protić i Laza Paču, pa je na njihovu preporuku upućen na specijalizaciju iz oblasti finansija. U Nemačkoj, Velikoj Britaniji i Francuskoj proveo je tri godine, a izvesno vreme radio je u okružnoj državnoj blagajni u Versaju i francuskom Ministarstvu finansija u Parizu. Po povratku u zemlju 1914. godine zaposlio se kao pisar u Ministarstvu finansija, a već 1918. nalazio se na položaju generalnog direktora, prvo Direkcije državnog računovodstva, a potom odeljenja državnih dugova i državnog kredita. Kako se u posleratnom vremenu mnogo više mogućnosti za zaradu pružalo u privatnom sektoru, napustio je Ministarstvo finansija i zaposlio se u Engleskoj trgovinskoj banci čiji je direktor uskoro postao. Od 1919. godine davao je stručne analize u javnosti i bio je saradnik Politike i dopisnik The Economist iz Londona, a od 1920. „Agence economique et financière" iz Pariza. ${ }^{1}$ Postao je potpredsednik Beogradske berze 1920. godine, a radio je i kao honorarni profesor finansija na Pravnom fakulte-

\footnotetext{
${ }^{1}$ Милан М. Стојадиновић, Ни рат ни пакт, Југославија између два рата, Ријека $1970,156$.
} 
tu u Beogradu. Postao je ministar 16. decembra 1922. kada je imao 34 godine i bio je ubedljivo najmlađi član vlade.

Treći put postao je ministar finansija zalaganjem kneza Pavla Karađorđevića u vladi Bogoljuba Jeftića 24. decembra 1934, a 8. januara 1935. imenovan je za senatora. ${ }^{2}$ Njegov dolazak na mesto ministra finansija po treći put zabeležen je i u stranoj štampi, a pariska berza propratila je ovaj događaj opštim skokom i tendencijom stabilnosti jugoslovenskih obveznica zajmova. ${ }^{3}$ Bio je glavni akter pada Jeftićevog kabineta 20. juna 1935, a dva dana kasnije Namesništvo mu je poverilo mandat za sastav nove vlade, koju je obrazovao 24. juna. Osim mesta premijera držao je i resor Ministarstva spoljnih poslova. Ocena njegovog mandata kao ministra finansija i premijera u stranoj štampi išla je dotle da je upoređivan sa Poenkareom, jer je kao i on spasio „u teškim položajima valutu svoje zemlje od kraha“. ${ }^{4}$ Bio je u dva navrata predsednik Beogradske berze, a drugi put izabran je maja 1937, kada je još uvek bio aktuelni premijer. ${ }^{5}$ Tokom mandata ministra finansija ili predsednika vlade često je bio na udaru političkih protivnika i optuživan je za korupciju i posrednu umešanost u mnogobrojne afere. ${ }^{6}$ Mišljenja i ocene o Milanu Stojadinoviću kretale su se u širokom rasponu - od ekonomskog genija do ,veštog blefera na pokeru“. 7

Prva dva puta na položaju ministra finansija Stojadinović je bio sa malim prekidom od 1922. do 1926. godine. Prilikom dobijanja mandata ekonomskofinansijska situacija u zemlji ogledala se u budžetskom deficitu, deviznoj krizi, inflaciji i skupoći. Stojadinović je brzo postao svestan da će na svom položaju imati dva šefa, kralja i predsednika vlade. Kralj Aleksandar I Karađorđević je bio zainteresovan prvenstveno za vojne potrebe, što je prejudiciralo izdatke, dok je Nikola Pašić mislio i na prihode, što je značilo dodatno opterećenje poreskih obveznika. $^{8} \mathrm{Uz}$ urgiranje za kredite za naoružanje vojske, prioriteti su bili obnova postradale zemlje, plaćanje invalidnina i kamata na konsolidovane državne dugove uvećane za obveznice Ratne štete i Agrarnog zajma.

Visoka inflacija, u velikoj meri izazvana konvertovanjem austrougarskih kruna u dinare Kraljevine SHS, dovela je do svakodnevnog zaduživanja države kod Narodne banke i stalnog uvećavanja novčane cirkulacije. Oskudica u proizvodima i materijalu za obnovu zemlje koji se nije mogao nabaviti na domaćem tržištu izazvala je i deviznu krizu. Devize iz Blerovog zajma bile su nedovoljne

${ }^{2}$ AJ, 37-95-529, Штампа, 10. јануар 1935, 3.

${ }^{3}$ Правда, Београд, 10.841, 6, 7, 8 и 9. јануар 1935, 2.

${ }^{4}$ Глас Канаде, Торонто, 92, 20. мај 1937, 1.

${ }_{6}^{5}$ AJ, 38-581-751, Време, Београд, 17. мај 1937.

${ }^{6}$ Politički pamfleti protiv Milana Stojadinovića bili su naročito aktuelni tokom 1935. i 1936. godine i dovodili su ga u vezu sa neuspelim aranžmanom sa firmom „Markoni” i izgradnjom radio-stanice u Beogradu, sa „Našičkom aferom”, aferom oko austrijskog osiguravajućeg društva „Feniks”. (AJ, 37-41-287, Pamfleti protiv Milana Stojadinovića).

\footnotetext{
${ }^{7}$ Република, Београд, 56, 17. јул 1924, 1.
}

${ }^{8}$ М. М. Стојадиновић, н. д., 165. 
da podmire potražnju za njima i razlika zvaničnog i slobodnog kursa dinara postajala je sve veća. Posledica svega bila je skupoća, koja se do Stojadinovića suzbijala administrativnim merama (maksimiziranjem cena, zabranom izvoza određenih proizvoda).

Stupanje na mesto ministra nije značilo hvatanje u koštac sa opštedržavnim problemima već, naprotiv, sa krajnje tekućim - obezbeđivanjem novca za isplatu činovničkih plata. Potez koji je prethodni ministar Kosta Kumanudi napravio pred odlazak sa mesta ministra jasno pokazuje da su partijski interesi bili ispred državnih. Državna blagajna je ispražnjena jer je Narodnoj banci iznenada vraćen dug od 100 miliona dinara. Jasno da je ovaj potez bio motivisan time da novom ministru finansija stvori veliki problem na samom početku rada, a ne željom da se smanji dug države emisionoj ustanovi. Stojadinović je, međutim, uspeo da vrati novac i prebrodi ovaj ,prvi test“".

Svoju finansijsku politiku Stojadinović je najavio rečima „ni inflacija ni deflacija“, mada je određen kontingent novčanica sistematski povlačen iz opticaja. I sam ministar je posle izvesnog vremena priznao ovu činjenicu. ${ }^{9}$ Deviznu krizu ublažio je na taj način što je, poznavajući mentalitet poslovnih krugova koji su se bavili trgovinom devizama, upotrebljavao i psihološka dejstva. Vrednost dinara prepustio je slobodnom tržištu, a zahvaljujući poziciji koju je imao u Engleskoj trgovinskoj banci na berzi su se pojavile devize i vest o sklopljenom zajmu, tako da je dinar počeo da jača. ${ }^{10}$ Sama objava da Ministarstvo finansija neće intervenisati da održi nerealan kurs dinara tokom prvog meseca izazvala je pad, tako da je januara 1923. doživeo najniži nivo i na berzi u Cirihu 100 dinara vredelo je 3 santima. Ministar je situaciju objasnio prvenstveno političkim razlozima. Okupacija Rurske oblasti i situacija na rumunsko-mađarskoj granici uticale su na pad i drugih valuta, a glasine u zemlji izazivale su dodatnu nervozu na berzama. Govorilo se o ostavci vlade, mobilizaciji usled prilika u regionu, velikim vanrednim vojnim kreditima. ${ }^{11}$ Posle toga, dinar je etapno jačao i 1925 . godine se ustalio na 9,13 santima za 100 dinara. $^{12}$ Jačanje dinara izazvalo je i povratak određenog kapitala građana, koji su u periodu inflacije štedeli novac u inostranim bankama.

${ }^{9}$ Govoreći o merama preduzetim za povećanje vrednosti dinara Stojadinović je naveo i to da je od oktobra 1923. do maja 1924. novčani opticaj smanjen sa 6 na 5,5 milijardi dinara (Jugoslavenski lojd, Zagreb 1965, 27. jun 1924, 1).

${ }^{10}$ Kako sam kaže, Stojadinović je upotrebio „psihološka sredstva hladnog rasuđivanja”. Kratkoročna pozajmica bila je svega 300.000 funti, ali brojka nigde nije bila saopštena. U situaciji kada je engleska banka prodavala funte, a na pragu bio inostrani zajam (kratkoročni neveliki zajam, mada suma nije saopštavana) „spekulantski” krugovi počeli su da se kolebaju u pogledu vrednosti dinara, tako da je ona počela da raste (M. M. Stojadinović, $n$. $d$., 167-168.

${ }^{11}$ Политика, 5.299, 24. јануар 1923, 1.

12 Odluka Milana Stojadinovića da uvede slobodan prometa devizama odmah je naišla na kritiku u Zagrebu. Smatralo se da „naglo” uvođenje slobodnog prometa devizama pogoduje samo spekulacijama nekih banaka, da se na berzi prave fiktivni niski kursevi, a mimo berza daleko veći (Novosti, Zagreb, 19. januar 1923, 1). 
Povećanje vrednosti dinara nije izazvalo pad cena, što je bio jedan od glavnih ciljeva Stojadinovićeve politike. Sudeći po reakciji javnosti, glavna povika bila je na trgovce na veliko, mada nisu samo oni održavali visok nivo cena. Uopšteno, bilo je puno otpora deflaciji, a time i korekciji cena. ${ }^{13}$ Među zainteresovanim za pad vrednosti dinara zbog zarade nalazile su se i neke banke, povezane sa trgovcima iz Beča, Trsta i Zagreba. U krugu inkrimisanih su se našle Slavenska banka DD iz Beograda i filijala Francusko-srpske banke u Zagrebu, koje su kupovale veće količine deviza u nameri da podignu njihov kurs. ${ }^{14}$

Grupa poslanika je isticala da se kurs dinara postiže i održava veštačkim načinom, dok su iz bankarskih krugova stizale kritike da se veštački sprečava prirodan skok dinara. ${ }^{15}$ Kritike da je novčana masa u opticaju mala za privredne potrebe zemlje i da je u poređenju sa zemljama u okruženju osetno niža, Narodna banka je pokušala da ublaži povećanjem novčane mase u nekoliko navrata, ali je taj novac uglavnom korišćen za intervencije na berzi. ${ }^{16}$ Bez obzira na sporadične intervencije Narodne banke, realan opticaj novca u većini evropskih zemalja bio je od $100 \%$ do $300 \%$ predratne količine, dok je u Kraljevini SHS iznosio svega $66 \%{ }^{17}$ Naglo povećanje tražnje dinara u Pragu, Beču i Cirihu prouzrokovalo je da kursevi u Beogradu padnu ispod pariteta, odnosno da devize budu jeftinije nego u inostranstvu. Krajem 1923. kursevi na berzama su se približili privatnim pa je većina novčanih transakcija počela da se obavlja na berzi, čime je ona ponovo preuzela kontrolu novčanih tokova u zemlji. Skok cena je zaustavljen i poverenje u dinar se lagano vraćalo, čemu je doprinelo i to da varijacije kursa dinara nisu bile tako osetne kao u prethodnoj godini. Prestanak sa inflatornom politikom izazvao je stagnaciju u novim poslovima. Smanjen je intenzitet rada, a nedovoljna i skupa proizvodnja i slabi rentabilitet zaoštrili su ekonomsku krizu u zemlji. Kritikovan je i nagli skok vrednosti dinara, jer se to loše odrazilo na izvoz, a time i na stabilnost vrednosti dinara. ${ }^{18}$ Naročito je Ivo Belin bio kritičar

${ }^{13}$ Политика, 5.336, 2. март 1923, 6.

${ }^{14}$ Slavenska banka je kažnjena sa 200.000 dinara za nesavestan rad i nedopuštenu spekulaciju, dok je filijala Francusko-srpske banke u Zagrebu kupovala devize iako ih je njihova centrala prodavala (Правда, 52, 23. фебруар 1923, 1; Нови живот, Београд, књ. XVI, св. 2, 10 новембар 1923, 64).

${ }^{15}$ Министарство финансија Краљевине Југославије 1918-1938, Београд 1938, 222.

${ }^{16}$ Mišljenje da je nevelika masa novca u opticaju isticali su i članovi Narodne radikalne stranke. U opticaju se januara 1923. nalazilo svega oko 415 dinara po glavi stanovnika (Samoupra$v a, 19,26$. januar 1923, 1). Demokrate su zamerale Stojadinovićevoj deflacionoj politici na tome što je ona uvedena bez pripreme, pa je Narodna banka morala da otkaže $10 \%$ kredita privredi, ali su priznavali da je ministar istrajao na svom pravcu i nije podlegao ni obećanjima ni pretnjama da se novac štampa (Народна слога, Панчево, 12, 24. август 1924, 1).

${ }^{17}$ Горан Николић, Курс динара и девизна политика Краљевине Југославије 19181941, Београд 2003, 99.

${ }^{18}$ Oporavak dinara ugrozio je izvoz, ali je osnovni problem nedovoljnog izvoza u stvari bila preskupa proizvodnja. Najnepovoljnije finansijsko stanje u Kraljevini Srbiji bilo je kada je zlatnik od 20 dinara plaćan 24 (ažija 20\%). Decembra 1923. njegova cena bila je 160 dinara (ažija 
monetarne politike iznoseći stav da je porast vrednosti valute štetan i po privredu opasan ako je prolazan. ${ }^{19}$ Mnoge kritika su bile politički motivisane i odisale su željom da se ne uspe u težnji da se dinar oporavi. ${ }^{20}$

Dodatnu stabilnost dinara dali su dugoročni zajam od 15 miliona švajcarskih franaka koji je Državna hipotekarna banka dobila od Švajcarskog bankarskog društva iz Bazela i 300.000 funti sterlinga od Uprave državnih monopola na zalogu duvana, čime je uvećan devizni stok Narodne banke. ${ }^{21}$ Stabilnost domaće valute bila je potvrđena i preko političkih činilaca. Oba pada vlade, Nikole Pašića u julu i Ljubomira Davidovića u novembru 1924, nisu izazvala perturbacije na tržištu novca. Službeno objašnjenje snaženja dinara bilo je da je ono posledica jačanja privrede. Tumačenja vanvladinih krugova ukazivala su na nestašicu dinara usled deflacije. Novca na tržištu nije imao niko, čak ni banke, pa je dinar zato bio skup. Što se tiče samog ministra finansija, njegova reakcija bila je da je pustio da se stvari razvijaju same po sebi. ${ }^{22}$ Iako je izvozni lobi bio protivnik jačanja dinara jer mu to nije išlo u prilog, i njegovi članovi dali su podršku finansijskoj politici ministra Stojadinovića na kongresu u Beogradu krajem avgusta 1924. godine.

Stalno jačanje dinara izazivalo je i bojazan da bi se mogli pojaviti neželjeni efekti. Povećanje vrednosti dinara pokazalo se kao ne manje zlo od pada i postavilo se pitanje njegove stabilnosti kao preduslova za uspešnu konkurentnost privrede na svetskom tržištu. Smanjenu konkurentnost domaće privrede Stojadinović je želeo da poboljša donošenjem nove carinske tarife koja bi favorizovala domaće proizvode $\mathrm{i}$ intervencijom na berzi u smeru sprečavanja rasta domaće valute. U dogovoru sa Ministarstvom finansija Narodna banka je pristupila otkupu svih količina deviza na berzi koje su mogle da slobodnom trgovinom utiču na skok vrednosti dinara, mada je sprovođenje deflacione politike zaduživanjem kod Narodne banke ocenjivano nezakonitim. ${ }^{23}$

U svakom slučaju, devizna politika je postala prepoznatljiva, pravilnici i ukazi su se proredili, smanjivao se devizni intervencionalizam, kursevi su postali slobodni a ne normirani. U isto vreme devizno tržište Kraljevine postalo je jedinstvenije i manjak na jednoj berzi popunjavan je viškovima na drugoj, a napredak telefonskog saobraćaja omogućio je bolju komunikaciju i manje razlike u kursevima berza u Beogradu i Zagrebu. Pošto je postignuta željena dinarska vrednost, saradnja Ministarstva finansija i Narodne banke u kreiranju i sprovođenju devi-

$800 \%$ ), a cena proizvedene robe ipak nije bila povoljna za inostranstvo (Самоуправа, Београд, 287, 2. децембар 1923, 1).

${ }^{19}$ Nova Evropa, Zagreb, knj. X, 1, 1. jul 1924, 31.

${ }^{20}$ Pad dinara u julu i avgustu bio je propraćen rečima da je finansijska politika Milana Stojadinovića „vođena više osećanjima nego pameti i nije postigla cilj kome je težila. Nastojanje da se dinar popne je propao“ (Исто, књ. Х, 6, 21. август 1924, 171). оград 1931, 88 .

${ }^{21}$ Душан Н. Узелац, Девизна политика Краљевине Југославије (1919-1929 год), Бе-

${ }^{22}$ Нова Европа, књ. Х, 12, 21. октобар 1924, 366-369.

${ }^{23}$ Политика, 6.061, 9. март 1925, 5. 
zne politike ogledala se $\mathrm{u}$ intervencijama koje bi sprečile fluktuaciju vrednosti dinara, $\mathrm{u}$ onemogućavanju da trenutne prilike i spekulacije utiču na stabilnost dinara i potrebi da se zakonom utvrde principi na kojima bi se zasnivala zaštita stabilnosti dinara. Izmenom zakona da ,novčanice izdate za kupovinu menica i čekova od strane pijace po tač. 1 čl. 11. Zakona o Narodnoj Banci ne ulaze u redovan kontingent koji Banka može izdati ako taj posao vrši za račun državni““ obezbeđena su banci sredstva sa kojima su se po nalogu Ministarstva finansija mogle sprečiti oscilacije dinara. Mada su politički oponenti omalovažavali finansijsku politiku Milana Stojadinovića, oni su ipak morali da priznaju da je u praksi davala pozitivne rezultate. ${ }^{24}$

I problem skupoće ministar je rešavao na način koji nije bio očekivan. Umesto zabrane izvoza i obaranja cena na domaćem tržištu, Stojadinović je odlučio da dozvoli slobodan izvoz čak i artikala koji su u zemlji bili hronična potreba (poput svinjske masti), i to bez izvozne carine. Skakanje cena na domaćem tržištu jeste bilo šok za stanovništvo, ali je on ubrzo neutralisan osetnim povećanjem proizvodnje, budući da je ona postala isplativa. Tako su cene u stvarnosti regulisane, država je dolazila do preko potrebnih deviza i ukinute su izvozne dozvole. „Izvoznice“" su ljudi na vlasti koristili kao mogućnost da se određeni kontingent u strogom režimu izvoza plasira na stranu, jer su najčešće prodavane trgovcima koji su želeli da robu izvezu. Slično je bilo i sa „uvoznicama“, pa je spoljna trgovina bila regulisana sistemom načelnih odluka koji su regulisali trgovačke tokove. Efektivni izdaci za uvoz smanjeni su pojačanom naplatom reparacija, manje u novcu više u naturi, ali u svakom slučaju država je obezbedila osetan prihod u budžetu. Stojadinovićev uticaj ogledao se u materijalu poručenom iz Nemačke. Dok je, do tada, vojska naručivala najveći deo potreba (čak i indigo hartiju), po logici „pošto je vojska dobila rat“, Stojadinović je, u cilju povećanja proizvodnje, stavio pod svoju kontrolu glavne tokove nabavka i uticao da se prvenstveno vrše nabavke mašina ili čitavih fabričkih instalacija. ${ }^{25}$

Najveći pritisak u pogledu rashoda vršilo je Ministarstvo vojske i mornarice, budući da je za njegove potrebe lično bio zainteresovan kralj Aleksandar. Stojadinović je uspeo da nađe kompromisno rešenje i izdejstvuje da Ministarski savet prihvati kratkoročno rešenje, za dopunu već postojećeg naoružanja, dok bi preuređenje celokupnog naoružanja bilo ostavljeno za finansijski povoljnija vremena. Uspeo je da Francuska vlada odobri ovaj projekat i on je sproveden u proleće 1924. godine. Smanjenje vojnog kadra nije dolazilo u obzir, jer je otvaranje ovog pitanja od strane ministra finansija ili vladine većine neumitno značilo smenu ministra ili pad vlade. Stojadinović se trudio da troškove oko nabavke na-

${ }^{24}$ Tako su demokrate kroz termine „slučajno” i „srećno” ipak posredno priznali da je politika aktuelnog ministra finansija postigla rezultate. Njihovo mišljenje o poziciji dinara, bez obzira na mnoge kritike upućene Stojadinoviću, najbolje se vidi po tome što su smatrali da je sazrelo vreme za stabilizaciju na zlatnoj podlozi i intenzivno to tražili (Правда, 165, 20. јун 1925, 1).

${ }^{25}$ М. М. Стојадиновић, н. д., 198. 
oružanja svede u okvire redovnog budžetiranja, a ne opterećivanjem države putem zaduživanja. ${ }^{26}$

Ostale važne mere koje je preduzeo bile su ukidanje letećeg duga kod Narodne banke, pridavanje većeg značaja neposrednom porezu, ali i uvođenje kuluka da bi se smanjili rashodi za puteve. U vladinim izveštajima o finansijskom stanju na dan 30. juna 1925. leteći dug države iznosio je 452.871 .736 dinara, što je u odnosu na kraj 1922. godine bilo manje za 948.511.297,35 dinara. ${ }^{27}$ Svim učinjenim Milan Stojadinović je uspeo da u roku od godinu i po dana u velikoj meri poboljša ekonomsko-finansijsku situaciju Kraljevine SHS. Izvoz je osetno porastao, inflacija je suzbijena, postepeno se povećavala vrednost dinara na međunarodnom tržištu. Tada su se u domaćoj i stranoj štampi pojavili natpisi o ,spasiocu dinara“. ${ }^{28}$

Prvi predlog budžeta koji je Stojadinović podneo bio je za 1923/24. godinu, a potom je izradio naredna dva. Nacrt prvog budžeta uzeo je od prethodnog ministra Koste Kumanudija, zbog termina kada je preuzeo portfelj ministra finansija. Kako su novi izbori zakazani već za 18. mart 1923, u nemogućnosti donošenja budžeta finansiranje je vršeno vanrednim i naknadnim kreditima u iznosu od 1,2 milijarde dinara. ${ }^{29}$ Utrošeno vreme za formiranje parlamenta uticalo je da se Stojadinovićev prvi nacrt sastojao od budžetskih dvanaestina, počevši od jula 1923. godine. $\mathrm{Na}$ ovaj način želja da se učini odlučan zaokret u načinu državnog budžetiranja, da se državni rashodi realno predvide i na taj način izbegnu vanredni krediti, nije mogla biti ostvarena. Određene budžetske partije su povišene, a ministar je odobrio određene sume pojedinim resorima iako one nisu bile zastupljene u budžetu. ${ }^{30}$ Javno mnjenje je primetilo da je vlada počela sa sprovođenjem štednje, ali nije izdržala, pa su se rashodi povećali. ${ }^{31}$

Narednim zakonom o budžetu predviđeno je da on mora biti potpun i da čini celinu, čime je zabranjeno neto budžetiranje, stvaranje aneksnih budžeta i vezivanje određenih prihoda za određene rashode. Članom 200 Finansijskog zakona za 1924/25. godinu utvrđeno je da budžetska godina traje od 1. aprila do

${ }^{26}$ AJ, 37-33-242, Ekspoze ministra finansija dr Milana Stojadinovića o predlogu budžeta za 1924/25. godinu.

${ }^{27}$ Славко Шећеров, Наше финансије 1918-1925, Београд 1926, 159.

${ }^{28}$ М. М. Стојадиновић, н. д., 173.

${ }^{29}$ Ova sredstva su isplaćena po članu 131 zakona o Državnom računovodstvu, koji je omogućavao ministru finansija da u pojedinim slučajevima može izvršiti kreditiranje i bez odobrenja i znanja Narodne skupštine. Opozicija je komentarisala opozicije kako je taj način isplate izvršen jer su potčinjeni činovnici odbili da izvrše nalog ministra finansija (Правда, 125, 8 . мај 1923, 1).

${ }^{30}$ Ministarstvu građevina odobreno je 60 miliona dinara za rekonstrukciju državnih puteva i 20 miliona za rekonstrukciju gvozdenih mostova (С. Шећеров, н. д., 81).

${ }^{31}$ Za održavanje automobila predsednika vlade i ministra spoljnih poslova trošeno je mesečno 20.000 dinara, aje za automobile ostalih ministara 15.000 dinara. Ovaj utrošak odnosio je dnevno 500 dinara po automobilu, što je bilo za 20 dinara više nego što je $40 \%$ invalida primalo za godinu dana (Политика, 6.361, 9. јануар 1926, 1 и 6.377, 25. јануар 1926, 5). 
31. marta iduće godine. ${ }^{32}$ Izborom ovog termina obezbeđeno je dovoljno vremena za pretres budžeta u Narodnoj skupštini, a predvideo ga je prethodni ministar. Da je politikanstvo bilo iznad državnih interesa može se videti po tome što je padom demokratskog kabineta ovaj datum kritikovan kao „proizvoljan“. ${ }^{33}$

Interesantno da je Stojadinović smanjivao rashode u odnosu na Finansijski odbor, mada je po opisu posla trebalo da bude obrnuto. Prilikom izrade budžeta za 1924/25. godinu čitava opozicija ga je kritikovala da je precenio prihode. Ipak, zahvaljujući stabilnoj vrednosti dinara, pojačanoj poljoprivrednoj konjunkturi i aktivnom spoljnotrgovinskom bilansu, budžetska godina završena je suficitom od 298 miliona dinara. ${ }^{34}$ Veći deo prihoda od predviđenih dali su prihodi ministarstva saobraćaja, vozarinske takse, trošarine i takse, monopoli, porez na poslovni promet i neposredni porezi. Bez obzira na povoljan odnos prihoda i rashoda, način trošenja novca nije se mnogo razlikovao od prethodnih budžeta. Za Ministarstvo vojske predviđeno je oko 2 milijarde dinara, dok su ministarstva prosvete, poljoprivrede i agrarne reforme zajedno dobila 816 miliona dinara. Osim vojske i činovništva, visoku stavku činilo je pet dispozicionih fondova sa oko 95 miliona dinara. Očito su politički razlozi i dalje prevladavali nad mnogim potrebama, tako da su odvajanja za „nacionalnu stvar“ bila visoka. ${ }^{35}$ Glavni izvor državnih finansija i dalje su bili posredni porezi, koji su davali 54\% svih prihoda.

Česte smene vlada i opstrukcija rada od strane Hrvatske seljačke stranke svodila su sprovođenje državnog budžeta na ličnu odgovornost ministra finansija i njegovu spremnost da se odupre zahtevima kolega iz vlade za povećavanje rashoda. Iako su rashodi nominalno rasli, što je trpelo kritike, uspešnost u rukovođenju državnim finansijama zadržana je i dalje, mada je deo kredita prevaljivan na narednu budžetsku godinu. ${ }^{36}$ Zato je realno sagledavanje stanja državnih finansija veoma teško jer je Stojadinović uveo praksu trošenja ne ostvarenih već očekivanih viškova prihoda.

Stalno povećanje rashoda opomenulo je Stojadinovića da je štednja postala preka potreba. Iz tih razloga, 25. maja 1925. uputio je pismo finansijskom odboru u kojem ga je pozvao na saradnju i što strožu štednju. Poresko opterećenje je dostiglo maksimum, uvođenje novih poreza je nemoguće i jedini izlaz je u povećanju prihoda efikasnijim prikupljanjem poreza - ocenio je Stojadinović.

32 Budžetske godine 1919/20, 1920/21. i 1921/22. počinjale su 1. juna, dok je 1922/23. trajala od 14 četrnaest, a druga 9 meseci.

${ }^{33}$ Политика, 5.653, 19. јануар 1924, 3.

${ }^{34}$ Министарство финансија, 28.

${ }^{35}$ Стенографске белешке Народне скупштине Краљевине Срба, Хрвата и Словенаияа, Редован сазив за 1923/24, књ. I, Београд 1924, излагање Косте Куманудија, 519.

${ }^{36}$ Budžetsku politiku Milana Stojadinovića kritikovali su članovi Jugoslovenskog kluba, a najviše se zameralo na povećanju budžeta rashoda. U suštini, iako su rashodi nominalno povećavani, oni za razliku od prethodnog perioda često nisu ispunjavani, tako da je budžetski ekvilibr i dalje zadržan (AJ, 37-32-239, Odvojeno mišljenje članova Jugoslovenskog kluba o budžetskim dvanaestinama za 1925/26. godinu). 
Železničke i poštanske tarife takođe su bile visoke i jedan od prvih zadataka finansijske politike vlade i skupštine bila je stroga štednja. U suprotnom, budžetska ravnoteža se nije mogla ostvariti.

Finansijski odbor sastavljen od vladine većine nije pokazao previše razumevanja, pa je smanjenje rashoda za druge $4 / 12$ u odnosu na prve u visini od 36 miliona dinara poteklo od samog ministra. Odgovor odbora bio je: „Finansijski odbor nalazi, da se štednja ne može vršiti jedino smanjivanjem cifara predloženih rashoda već i razgledanjem i pretresanjem kako državne administracije, tako i njenih funkcija i potreba, pa izvesne ukinuti a druge reorganizovati te na taj način ukloniti uzroke visokih ili nepotrebnih rashoda. Da bi se ovaj zadatak obavio, Finansijski odbor se podelio u sekcije radi lakšeg i uspešnijeg rada. Ovaj Odbor će nastaviti rad po sekcijama i rezultati tako brižljivog proučavanja nesumnjivo će se povoljno odazvati u pogledu smanjivanja rashoda“".

Od 1921. godine do dolaska Stojadinovića na mesto ministra investicije su pokrivane Investicionim i Blerovim zajmom. Stojadinović je uglavnom iskoristio neutrošene i neangažovane sume iz dolarskog zajma i pokrivao je investicije iz redovnih tekućih prihoda. Prestankom pokrivanja budžetskih deficita letećim dugom kod Narodne banke, više pažnje posvećeno je ubiranju prihoda od neposrednih poreza, koji nisu ni približno adekvatno naplaćivani. Privredni polet osetio se preko porasta cena, povećanja obima spoljne trgovine, ali i u uspešnijoj naplati državnih prihoda. Ukoliko se uporede cene proizvoda 15. februara 1923. sa 15. februarom 1924. stanje je bilo sledeće: goveđe meso 14-16 dinara za kilogram prema 20-26 dinara; teleće meso 16-20 prema 25-30 dinara; jagnjeće meso $20-40$ prema $36-45$ dinara; svinjetina $28-30$ prema $34-38$ dinara; suva slanina 36 prema 40-44 dinara, mast 36-38 prema 36-39 dinara; spanać 5-9 prema 10-15 dinara; pasulj 4,5-6 prema 8-12 dinara. ${ }^{38}$ Slično je bilo i sa cenama industrijske robe, a zbog stanja na svetskom tržištu pala je cena žitu i kukuruzu. Ukoliko se uvaži i porast vrednosti dinara, postaje jasno da su vrednost proizvoda i kupovna moć stanovništva bili u porastu. O povoljnijem stanju u javnim finansijama u odnosu na prethodne godine svedočili su natpisi u stranoj štampi. ${ }^{39}$

Poreski sistem je bio progresivan, a kod zemljoradnje se obračunavao po čistom katastarskom prinosu. Porez koji je posle rata zemljoradnik plaćao bio je neznatan. Vrednost dinara u odnosu na zlato smanjena je 16 puta, pošto je napoleon stajao 320 dinara. Seljak je, kako se govorilo, mogao da od prodaje jedne kokoške izmirio ceo svoj jednogodišnji porez. Stojadinović je predložio da se zavede vanredan prirez od $500 \%$, što je značilo da se porez na zemlju povećao

\footnotetext{
${ }^{37}$ С. Шећеров, н. д., 149.

${ }^{38}$ Исто, 111-112.
}

${ }^{39} \mathrm{U}$ italijanskoj štampi početkom 1924. godine Kraljevina SHS je prikazana kao država koja poboljšava svoje finansije, o čemu govori i članak u listu Il memento economico, Milano, 2.172, 15. januar 1924, 1 pod naslovom „Uno stato che migliora le sue finanze - La Yugoslavia”. Da je finansijska politika bila na dobrom putu pisao je i češki Gazet de Prag (Самоуправа, 115, 26. мај 1923, 5). 
pet puta. Umesto kokoške, seljak bi imao da proda tele ili dve svinje pa da izmiri dužan porez. ${ }^{40}$

Prevaljeni krediti iz prethodnih godina uticali su da je budžet za 1925/26. godinu preko dvanaestina predviđen na čak 12,3 milijarde dinara. ${ }^{41}$ Zato je invalidski porez udvostručen, a utvrđeno je da će se naplaćivati i komorski prirez u visini jednostrukog iznosa invalidskog poreza. Ovakve mere nisu odobravali ni svi poslanici iz vladine većine, a pritisak koji je vršen na radikalske poslanike da glasaju za budžet Mihailo Ranković propratio je rečima: „Ako glasaš za budžet, radiš protivu naroda i svoje svesti; ako glasaš protivu udružujem se sa Spahom i ostalim protivdržavnim elementima“. ${ }^{42}$ Ipak, bez obzira na sve primedbe, Stojadinovićevi potezi za vreme prva dva mandata dali su mnogo više rezultata od neželjenih efekata.

Dolazak na mesto ministra finansija po treći put krajem 1934. godine i na mesto premijera pola godine kasnije ponovo je predstavljao izazov za privrednofinansijske poteze Milana Stojadinovića, budući da je svetska recesija i dalje postojala. Uredbom od 15. januara 1935. ukinut je zbog neisplativosti revolving kredit Narodne banke od 314 miliona francuskih franaka (942 miliona dinara) podignut na podlozi jugoslovenskog zlata, a predviđeno je da se zlatna i devizna podloga više ne mogu koristiti za ovakvu vrstu kredita. Minimalno zakonsko pokriće novca u opticaju prilagođeno je mogućnostima i potrebama i smanjeno sa $35 \%$ na $25 \%$, odnosno $20 \%$. Podloga je vrednovana sa zvaničnim primom čime je priznata devalvacija dinara, dok se zlato Narodne banke moralo držati u zemlji, a ne inostranstvu. ${ }^{43}$ Stojadinović je kao predsednik vlade postavio zadatak da povrati privredni prosperitet države i pripremio je ambiciozan program. „Nova ekonomska politika“ bila je u znaku sve veće državne intervencije u privredi, što je karakteristično i za druge evropske zemlje. Osnova te politike bilo je širenje državnih preduzeća, kao i program proizvodnog oporavka, koji se u velikoj meri oslanjao na uvođenje javnih radova. Za ministra finansija postavio je iskusnog činovnika Dušana Leticu, koji je na najbolji način sprovodio premijerove zamisli.

Sprovedena je umerena deflaciona politika, koja je podrazumevala smanjivanje činovničkih plata, obezbeđivanja izvoza poljoprivrednih proizvoda i stabilizaciju prihoda od poljoprivrede, podsticanja industrije uz pomoć umerenih zaštitnih carina, popravljanje trgovinskog bilansa, industrijsko-privredne autarhije, ali i intenziviranje naoružanja. Osnovna načela finansijske politike bila su: održanje i jačanje zlatne podloge, ali bez apsolutne, dogmatične vezanosti novčane jedinice za određenu količinu zlata i održanje stabilnosti dinara u svetskom

${ }^{40}$ М. М. Стојадиновић, н. д., 494.

41 Лаза Костић, Адам Максимовић, Зборник финансијских закона од 1919-1939/40, Нови Сад 1939, 238.

${ }^{42}$ Смотра, Београд, 22, 18. април 1924, 1.

43 Народно благостање, 5, 26. јануар 1935, 67 и Стенографске белешке Народне скупитине Краљевине Југославије, Ванредан сазив за 1935. годину, Београд 1935, књ. II, излагање министра финансија Душана Летице и мишљење Финансијског одбора, 2-7. 
prometu pomoću celishodne devizne politike. ${ }^{44}$ Da bi se ojačala podloga u zlatu Narodna banka je od Ministarstva finansija dobila ovlašćenje da otkupljuje svo zlato proizvedeno u zemlji po kursu na svetskim berzama. ${ }^{45}$

Dobivši preferencijalne cene za poljoprivredne proizvode od Nemačke Stojadinovićeva vlada je uspela da drastično poveća spoljnotrgovinsku razmenu i ostvari pozitivan bilans koji je bio garant stabilnosti valute i budžeta. Pozitivan budžetski saldo ponovo je postao praksa, ali je politička klima uoči izbijanja Drugog svetskog rata uticala na to da je znatan deo sredstava odlazio na naoružanje. Često primenjivana mera za trenutnu popunu državnog budžeta u ovom periodu bilo je emitovanje blagajničkih zapisa. Da bi lakše došla do sredstava i povratila poverenje stanovništva u državne emisije hartija od vrednosti, država je još 1935. godine plasirala prvi deo zapisa sa srednjoročnim obavezama za izvođenje javnih radova. Osim preko zapisa država se zaduživala putem zajma za javne radove i specijalnim blagajničkim bonovima za narodnu odbranu. Cilj javnih radova bio je ublažavanje posledica privredne krize i stvaranje mogućnosti za rad. Radom je bila obezbeđena zarada koja je povećala potrošnju i promet, čime je oživljavan privredni život.

Procenivši da je poresko opterećenje građana bilo previsoko, vlada je od 1935. godine pristupila stalnom smanjivanju procenta poreskih obaveza građana u budžetu. Smanjeni su porez na oranice i vinograde, smanjeni su banovinski prirezi, niz taksa je ukinut ili su im stope snižene, dok je trošarina na pogonska sredstva ukinuta. Za manje i srednje poreske obveznike sniženi su poreski dugovi, a otplata poreskih dugova zemljoradnika i sitnih zanatlija produžena je za 15 godina. Dobrovoljcima i kolonistima produžene su poreske povlastice kod zemljarine za pet godina, što je osim privredne imalo i socijalno-političku konotaciju. Da bi se olakšalo podizanje javnih skladišta, naročito za žito, taksa za podizanje smanjena je na jednu desetinu pređašnje, što je bio podsticaj za poljoprivredu i trgovinu. Delimična naknada za gubitak prihoda pronađena je uvođenjem novih i uopštavanjem nekih već uvedenih trošarina, ali stopa opterećenja nije donosila osetnije izdatke potrošačima. Državna administracija je upućena na vanredno ekonomisanje sa odgovarajućim kvotama budžetskih kredita, a pristupilo se i likvidaciji određenih kredita. Bez obzira na povećano interesovanje vlade za ekonomisanjem, lični izdaci i dalje su bili daleko najveća stavka u budžetu, mada se Jugoslavija po tome nije razlikovala od zemalja u regionu.

Izuzetno problematično pitanje zemljoradničkih dugova rešeno je uredbom koja je doneta 26. septembra 1936. godine. Posao likvidacije prema novčanim zavodima i kreditnim zadrugama poveren je Privilegovanoj agrarnoj banci. Banka je preuzela od zavoda menični portfelj zemljoradnika i obavezala se da

${ }^{44}$ AJ, 38-579-746, M. Nedeljković, Narodna banka kao središte naše narodne privrede, govor na XVIII redovnom zboru akcionara.

${ }^{45}$ Od Francuskog društva borskih rudnika Narodna banka je u 1937. godini otkupila $1.812 \mathrm{~kg}$ zlata, u 1938. godini $1.831 \mathrm{~kg}$ a u 1939 . godini $115,5 \mathrm{~kg}$ (AJ, 70-466-771, Izveštaj Narodne banke ministru finansija Vojinu Đuričiću od 16. februara 1939). 
isplati u visini od 50\% od glavnice duga u roku od 14 godina u jednakim godišnjim anuitetima, a za $25 \%$ izdala je $3 \%$ obveznice za likvidaciju zemljoradničkih dugova. Prilikom procesa prijavljivanja potraživanja evidentirano je 652.000 dužnika i 4.098 ustanova, dok je prijavljeno potraživanje dostiglo sumu od 2 milijarde i 747 miliona dinara, što jasno govori o veličini problema i obimu posla. ${ }^{46}$ Cene poljoprivrednih proizvoda porasle su za 30-40\%, radničke nadnice u proseku za $40 \%$, a činovničke plate za 20\%. Redovno su isplaćivana bolovanja, socijalna pomoć i penziono osiguranje. Vrednost potrošačke moći stanovništva uticala je na povećanje broja trgovinskih radnji i vrednost prodaje u nacionalnoj trgovini za $87 \%$. Nemačka je davala preferencijalne cene $20 \%$ više od tržišnih, dok su svi industrijski proizvodi nabavljani $40 \%$ jeftinije, koliko je nemačka vlada doplaćivala izvoznicima iz svojih sredstava. ${ }^{47}$

Vlada je zaključila 18 novih trgovinskih i platnih sporazuma što je dodatno povećalo rast obima spoljne trgovine. ${ }^{48}$ Podstican je uvoz iz zemalja sa kojima je imala klirinške sporazume i tako je sprečavan odliv deviza, što je uticalo na stabilnost domaće valute. ${ }^{49}$ Kupovna moć seljaštva u ovom periodu je povećana jer su cene agrarnih proizvoda bile osetno više, što je posredno uticalo i na oporavak industrije i trgovine, a time i povećanje državnih prihoda. Ove okolnosti omogućile su vladi da uspešnije realizuje svoj socijalno-ekonomski program, pa je program javnih radova povećao stopu zaposlenosti, dok su nadnice povećane usled velikog broja štrajkova, često podržavanih od same vlade. Važnu stavku do izbijanja rata u Evropi činile su doznake iz inostranstva, koje su ponovo postale značajnije usled jenjavanja ekonomske krize u svetu.

Tokom 1935. godine prihodi su povećani, a rashodi su smanjeni za $15 \%$ što je uticalo da se budžetska godina završila suficitom od 436 miliona dinara. Prihodi su povećani izdavanjem prava na eksploataciju državne zemlje, kao i radom državnih preduzeća, čime je vlada dobila budžetski prihod od 52,3 miliona dinara. ${ }^{50}$ Prihodi su delom bili umanjeni poštovanjem odluke Društva naroda o sprovođenju sankcija protiv Italije. Drvna industrija se našla u veo-

${ }^{46}$ Министарство финансија, 260. (Utvrđivanjem visine zaduženja zemljoradnika prestalo je i preuveličavanje ukupne sume zaduženja, koja je u Narodnoj skupštini procenjivana na 6 , čak i 7 milijardi dinara, Стенографске белешке, II Редован сазив за 1933/34, излагање Богољуба Кујунџића, 30).

${ }^{47}$ М. М. Стојадиновић, н. д., 496.

${ }^{48}$ Ekonomski boljitak vidi se i iz kotiranja Seligmanovog zajma: od 55 dolara na nominalnih 100 tokom 1934. do 100,5 u novembru 1937. Obim spoljne trgovine povećan je sa 3,7 milijardi 1934. na 6,3 milijardi 1937. godine (Исто, 496-497).

${ }^{49}$ Ova mera nije bila popularna i kao prvu reakciju izazvala je nezadovoljstvo u trgovačkim krugovima u zemlji. Međutim, ona je gotovo $u$ potpunosti ispunila svoj cilj, jer je negativan bilans sa neklirinškim zemljama smanjen sa 415,6 na 104,3 miliona dinara (Živko Avramovski, Britanci o Kraljevini Jugoslaviji, Godišnji izveštaji Britanskog poslanstva u Beogradu 1921-1938, II, Beograd-Zagreb 1986, 501).

${ }^{50}$ Мари-Жанин Чалић, Социјална историја Србије 1815-1941, Успорени напредак индустријализацији, Београд 2004, 388. 
ma teškom položaju, pa je to bila prva grana privrede u kojoj je država intervenisala.

„Budžet za 1936-37. godinu ne nosi samo karakter jednogodišnjeg državnog proračuna, nego simbolizuje prvu pobednu etapu borbe ka demokratiji i parlamentarizmu“.51 Ove reči objavljene u glasilu Jugoslovenske radikalne zajednice zračile su elanom, optimizmom i propagandom koji su simbolizovali izlazak iz krize i trebalo je da najave početak osetnog poboljšanja svih aspekata javnog i privatnog života u Jugoslaviji. Isticano je da je finansijska politika zasnovana na pravednoj podeli poreskih tereta i racionalnoj štednji, kao i da je ovo prvi budžet od ujedinjenja i stvaranja Kraljevine SHS u kojem nisu povećane već smanjene poreske obaveze. Od ovog budžeta procene prihoda državnih privrednih preduzeća nisu više odvajane u posebnim stavkama. Uveden je princip tzv. budžetskog jedinstva i ovakav način prikazivanja budžeta ostavljao je vladi veće slobode $u$ raspodeli sredstava tokom godine. Vlada je najavila veća ulaganja u materijalne rashode budžeta, sa ciljem da ojača oronulu potrošačku snaga pretežnijeg dela naroda, onog koji se bavio proizvodnjom materijalnih dobara. Rashodi su smanjeni, a nepokriveni krediti prikazani su u računskom delu predloga budžeta. Ovakav pristup ukazuje na nameru vlade da proba sa realnom štednjom u državnoj ekonomiji, pa su smanjeni dodaci vladinim činovnicima i penzionerima. Godina se završila rekordnim suficitom od oko 559 dinara. ${ }^{52}$

Naredni budžet je drastično povećan, ali je to učinjeno prvenstveno iz želje da se odustane od prakse uvođenja rashoda u poslednjem trenutku, koji nisu mogli biti pokriveni. Budžet je okarakterisan kao „,predlog radova koje vlada i ministar finansija žele da zavedu“. ${ }^{53}$ Nastavljeno je smanjenje rashoda za lična primanja i ostale troškove. Iako je kriza ublažena, nije bilo moguće povećati fiskalno opterećenje. Pažnja je obraćena i na prodor stranog kapitala, koji se sve više učvršćivao u zemlji zahvaljujući kolapsu privatnog bankarstva. ${ }^{54}$

Ekonomskom oporavku zemlje umnogome su doprineli rekordni prinosi pšenice i kukuruza, tako da je država imala veliku zaradu od izvoza. ${ }^{55}$ Vladin leteći dug smanjen je sa 2,9 milijardi dinara u 1935. godini na 1,229 milijardi u oktobru 1938. godine. ${ }^{56}$ Ipak, veliko povećanje prihoda nije osetno poboljšalo životni standard. Država je strogo naplaćivala indirektne poreze i dažbine u svim fazama proizvodnje i prodaje, što je uticalo na dalji rast cena. Plate radnika i činovnika nisu rasle srazmerno povećanju troškova života, tako da oni nisu mogli osetiti porast blagostanja, što se odrazilo na povećanje radničkih nemira. I dalje

${ }^{51}$ Самоуправа, 7, 27. фебруар 1936, 1.

${ }^{52}$ Министарство финансија, 32.

${ }_{53}^{53}$ Самоуправа, 71, 29. март 1937, 4.

${ }_{54}$ AJ, 38-568-735, Југословенски лојд, 19. март 1937.

${ }^{55}$ U 1937. godini zabeležen je rekordan prinos kukuruza od 53,32 miliona metričkih cent (AJ, 74-86-127, Izveštaj Upravnog odbora Udruženja bankarskih i osiguravajućih preduzeća Novi Sad, za poslovnu godinu 1937,3$)$.

${ }^{56}$ Ж. Аврамовски, н. д., II, 700. 
su se mogli čuti komentari o potrebi redukcije činovništva, ali vlada nije preduzimala mere otpuštanja službenika. Najveći porez od službeničkog poreza naplaćen je u Savskoj banovini i iznosio je čak 29,1\% činovničkog poreza, što je značilo da je u ovoj banovini bio najveći broj nameštenika. Potom su sledili Beograd sa $16,7 \%$, pa Dravska i Dunavska banovina. ${ }^{57}$ Povećanje prihoda bilo je prilika da se vlada oslobodi dugova prema činovništvu. U cilju štednje službenicima su od 1. oktobra 1935. smanjene prinadležnosti. Vlada je odvojila 240 miliona dinara da reguliše ova dugovanja, ali je predviđena suma novca bila nedovoljna, tako da je činovništvu vraćena suma koja je iznosila oko polovine one koja im je bila oduzeta. $^{58}$

Reči hvale mogle su se primetiti i u delovima zemlje u kojima su se nalazili njeni politički oponenti: „Uspehe gospodina dr Stojadinovića priznaju i najokoreliji Hrvati i mnogi naglasuju da bi šteta bilo kad bi prilike donijele da njegove sposobnosti ostanu neupotrebljene“. ${ }^{59}$ Porast cena poljoprivrednih proizvoda od $80 \%-100 \%$ u odnosu na nekoliko prethodnih godina, povećani izvoz i promet robe doveli su do popravljanja prilika u zemlji i gotovo likvidiralo nezaposlenost $\mathrm{u}$ određenim krajevima. ${ }^{60}$ Povećanje broja zaposlenih lica putem javnih radova itekako je korišćeno kao propaganda u korist vlade, pa su u pojedinim glasilima iznošene tvrdnje da nezaposlenost više i ne postoji. ${ }^{61}$ Prema podacima Središnjeg ureda za osiguranje radnika maksimalan broj osiguranika iznosio je 721.021, dok je prosečna obezbeđena nadnica krajem decembra 1937. iznosila 22,71 dinara. Od 15. aprila 1937. stupila je na snagu Uredba o utvrđenju minimalnih nadnica, a 1. septembra uvedeno je osiguranje radnika za slučaj iznemoglosti, starosti i smrti za sva lica koja su bila obavezna na osiguranje. Osim toga, od 1. januara 1938. postala je važeća uredba kojom se penziono osiguranje privatnih nameštenika proširilo na teritoriju cele države, a doneta je i uredba o zbrinjavanju nezaposlenih radnika. Ipak, neznatno povećanje dnevnica nije moglo da nadoknadi porast cena, a indeks radnika obuhvaćenih osiguranjem porastao je tokom godine sa 109,9 u januaru 1938. na 133,8 u avgustu, da bi u januaru 1939. opao na $114,1{ }^{62}$ Sve navedene uredbe značile su opterećenje privrede od 245 miliona dinara godišnje. Ako se ovoj sumi doda i opterećenje za radničko zdravstveno osiguranje, celokupno godišnje opterećenje privrede iznosilo je 645 miliona dinara. ${ }^{63}$ Period od druge polovine 1937 . do juna 1938 . bio je period najvećeg prirodnog poleta.

${ }^{57}$ Народно благостање, 28, 10. јул 1937, 439.

${ }^{58}$ Исто, 10, 9. октобар 1937, 652.

${ }_{59}$ Држава, Сплит, 42, 4. новембар 1937, 1.

${ }^{60}$ Наме слово, Суботица, 197, 25. децембар 1937, 1.

${ }^{61}$ Јаван рад, Београд, 10-12, 1937. година.

1946,27

62 Др Љубомир Дуканац, Индекси коюунктурног развоја Југославије, Београд

${ }^{63}$ AJ, 74-86-127, Izveštaj Upravnog odbora Udruženja bankarskih i osiguravajućih preduzeća Novi Sad, za poslovnu godinu 1937, 4. 
Vlada je bila ponosna na rezultate svoje privredne politike i ministar Letica je izjavio da je ,pokriće budžetskih potreba države traženo i nađeno u činjenici povećanja današnjih budžetskih prihoda, a to sve kao posledica jačeg pulsiranja privrednog života i jačanja potrošačke snage naroda“". ${ }^{64}$ Ovakvu izjavu ministra pratila je i činjenica da je povećanje državnih prihoda nastavljeno u zimskim mesecima i nije stalo posle žetve, kao što je obično bio slučaj. Poreski aparat je bolje funkcionisao, pa su najveći porast postigli prihodi od neposrednih poreza. Povećanje se beležilo i kod tečevine i službeničkog poreza. Pojačani uvoz povećavao je carinske prihode ${ }^{65}$ Finansijskim zakonom za 1938/39. godinu predviđeno je da se „materijalni“" rashodi mogu vršiti samo do iznosa od $90 \%$ odobrenih sredstava, što je bio nagoveštaj da je vlada svetsku krizu shvatala ozbiljno i da je bila svesna da ona može smanjiti državne prihode.

Radi regulisanja platnog prometa sa inostranstvom ustanovljen je pri Narodnoj banci, Komitet za uvoz. ${ }^{66}$ Činili su ga predstavnici Narodne banke, predstavnik Ministarstva finansija i dva predstavnika Ministarstva trgovine i industrije i Ministarstva inostranih poslova. Ideja je bila da se stane na put slobodnom uvozu iz država sa kojima je Jugoslavija imala pasivan trgovinski bilans i da se spreči nepotreban izvoz deviza za artikle koji su spadali u kategoriju luksuznih ili su mogli biti dobavljeni iz klirinških zemalja. Kontrola uvoza robe iz neklirinških zemalja bila je političko-valutarna mera, što se vidi iz sastava Komiteta, a počela je da se primenjuje od 25. juna 1936. i dala je povoljne rezultate. Otklonjene su posledice dotadašnje politike da jugoslovenska trgovina prema neklirinškim zemljama bude pasivna za nekoliko stotina miliona dinara, dok je za isto toliko novca bila aktivna prema klirinškim zemljama. ${ }^{67}$ Aktivna spoljna trgovina i poboljšano stanje deviznog položaja od 1935. omogućili su napuštanje kliringa i plaćanje robe devizama sa Francuskom, Švajcarskom i Belgijom. Ipak, pasivan trgovinski bilans sa neklirinškim zemljama, visoka potreba uvoza i nestanak Austrije koja je veliki deo svojih plaćanja vršila u devizama, pretili su velikim padom vrednosti dinara. Najsigurnija valuta postao je američki dolar, a pretvaranje je vršeno direktno ili preko britanske funte. Vlada je preko resornog ministarstva primenjivala strogu kontrolu devizne i spoljnotrgovinske politike, pa je dinar sve do nemačkog napada na Jugoslaviju 1941. godine po zvaničnom kursu bio stabilan. Povećan je broj artikala za koje se nisu mogle dobiti devize, visina izvozničkih deviza koje su banke po zvaničnom kursu morale prodati Narodnoj banci

${ }^{64}$ Народна слога, Београд, 9, 1. децембар 1937, 1.

${ }^{65}$ Народно благостање, 3 , 15. јануар 1938, 39.

${ }^{66}$ Службене новине, 82, 9. април 1936.

${ }^{67}$ Primer uspešnosti rada Komiteta, Ministarstvo finansija je predstavilo na primeru Velike Britanije. Tokom 1935. vrednost uvoza robe iz ove države iznosila je 373.445.181 dinar, a izvoza 212.266.940 dinara, uz pasivan bilans od 161.178.241 dinar. Već 1937. godine izvoz u Britaniju iznosio je 464.620.265 dinara a uvoz 409.140.626 dinara, odnosno uz aktivan bilans od 55.479.639 dinara. Slično je bilo i u trgovinskim odnosima sa SAD, Japanom, Danskom, Holandijom (Министарство финансија, 230-231). 
povećana je na polovinu, destimulisan je uvoz iz neklirinških zemalja, itd. U strahu da promena cene zlata ne destimuliše izvoz Narodna banka nije menjala njegovu vrednost, iako je ona porasla na međunarodnom tržištu. Ova mera dovela je do njegovog ilegalnog iznošenja iz zemlje. ${ }^{68}$

Namera vlade da se poveća količina metalnog novca u opticaju istaknuta je Zakonom o povlačenju iz opticaja starog i kovanju novog metalnog novca. ${ }^{69}$ Obrazlažući potrebu povećanja metalnog novca u opticaju ministar finansija Dušan Letica istakao je da je u Nemačkoj u cirkulaciji 423 dinara po glavi stanovnika, Austriji 149, Bugarskoj 121 a u Poljskoj 99. U Jugoslaviji je u tom trenutku opticaj bio 81 dinar po glavi stanovnika, dok bi se posle kovanja podigao na 97 dinara. $^{70}$

Likvidacija zemljoradničkih dugova značila je žrtvovanje privatnog bankarstva i oslonac na poludržavne banke. Zbog nedovoljnih sredstava iz realnih izvora bilo je neophodno animiranje štednje koja je od 1931. godine i svih nemilih događaja bila gotovo u potpunosti zamrla. Štedni ulozi su za četiri godine umanjeni za 4,122 milijarde dinara, što je činilo 30\% uloga. Uz moratorijum na dugove seljaka to je uticalo da se krajem 1935. godine od 620 privatnih banaka pod zaštitom nalazilo 239, pod sanacijom 11, a u vanstečajnoj likvidaciji 27 banaka. ${ }^{71} \mathrm{Na}$ Stojadinovićev predlog Državna hipotekarna banka, Poštanska štedionica i Privilegovana agrarna banka stavljene su u nadležnost Ministarstva finansija. Ove tri ustanove trebalo je da saradnji sa Narodnom bankom budu nosioci kreditnog sistema. ,Vlada želi da bolje organizuje novčano tržište putem jedne efikasne i racionalne koordinacije kreditnih izvora zemlje u cilju poboljšanja prometa kapitala, kao i celog bankarskog sistema uopšte“ ${ }^{72}$ Predviđana je elastičnija kreditna politika, kako bi se olakšao razvitak poslova i privrednih delatnosti. Zato je vlada podstakla Narodnu banku da sa Poštanskom štedionicom povoljnim kreditima omogući realnu sanaciju i rad novčanim zavodima. Početkom 1938. godine Poštanska štedionica je počela dodeljivati zajmove kreditnim zadrugama i njihovim savezima na osnovu predatih potraživanja od zemljoradnika Privilegovanoj agrarnoj banci. Novčani zavodi su bili zadovoljni ovom kreditnom službom, za razliku od načina na koji je to vršila Narodna banka. ${ }^{73}$

Vladina finansijska politika je uspela da stvori potpuno likvidno novčano tržište u 1938. godini sa sumom od 23 milijarde dinara raspoloživih sredstava plaćanja, što je bio apsolutan rekord u Kraljevini Jugoslaviji. Zahvaljujući ,zdra-

${ }^{68}$ Jugoslaviji je jedan sovrenj plaćan 376 dinara, dok je njegova cena u Velikoj Britaniji bila 416,5 dinara. (Г. Николић, н.д., 142).

${ }^{69}$ Служббене новине, 203, 8. септембар 1937.

${ }^{70}$ Министарство финансија, 233.

${ }^{71}$ AJ, 37-32-237, Izveštaj guvernera Narodne banke o privrednim prilikama, 15. februar 1936.

${ }^{72}$ Правда, 10.849, 17. јануар 1935, 3.

${ }^{73}$ AJ, 74-86-127, Izveštaj Upravnog odbora Udruženja bankarskih i osiguravajućih preduzeća Novi Sad za poslovnu 1937. godinu, 9. 
vom stanju“ na tržištu, uticaj Sudetske krize septembra 1938. i povlačenje uloga iz banaka nisu izazvali krizu poverenja upravo zbog intervencije Narodne banke i povećanja novčanog opticaja. Stabilnost novčanog tržišta potvrdila se već od oktobra, kada se visina štednih uloga za dva meseca povećala sa 10,7 na 11,228 milijardi dinara. ${ }^{74}$ Pomoć države novčanim zavodima i stvaranje solventnog bankarskog sistema bili su preduslov za uspešnost dugoročnog $6 \%$ unutrašnjeg državnog zajma u cilju izvođenja javnih radova i potreba zemaljske odbrane u visini od 4 milijarde dinara. Ovaj veliki zajam je predviđen članom 103 Finansijskog zakona za 1938/39. godinu i oslikava vladinu dugoročnu politiku, jer je emisija zajma predviđena postupno, u narednih šest godina. ${ }^{75}$ Do kraja 1938. godine od 632 novčana zavoda pod zaštitom se nalazilo njih 237 , u procesu sanacije bilo ih je 16, a u vanstečajnoj likvidaciji bila su 44 novčana zavoda. ${ }^{76}$ Ukupno stanje štednih uloga na dan 31. decembra 1930. iznosilo je 14,133 milijardi dinara, dok je 31. decembra 1937. bilo 11,77 milijardi dinara. Osim što je visina štednih uloga usled krize smanjena za preko dve milijarde dinara, primetna je i promena poverenja štediša u tip banke. Porast uloga kod državnih banaka u ovom periodu iznosio je 1.894.397.168,20 dinara, odnosno visina uloga kod privatnih zavoda smanjena je za 4,256 miliona dinara. ${ }^{77}$

${ }^{74}$ Борис Кршев, Банкарство у Дунавској бановини, Нови Сад 1998, 123.

75 Л. Костић, А. Максимовић, н. д., 820.

${ }^{76}$ Б. Кршев, $н . \partial ., 123$.

${ }^{77}$ AJ, 74-86-127, Izveštaj Upravnog odbora Udruženja bankarskih i osiguravajućih preduzeća Novi Sad za poslovnu 1937. godinu, 28. 
Ivan M. Becić

\section{MILAN STOJADINOVIĆ'S FINANCIAL POLICY}

\section{Summary}

Yugoslav Prime Minister Milan Stojadinović was a finance minister for a three times, and as prime minister 1936/1939, he was a key responsible factor of a Kingdom financial policy. He gain his basic experience while working in French Ministry of Finance, and later developed a firm contacts within the banking and financial circles. As Minister of Finance, Stojadinović enjoyed a excellent reputation, even among the citizens. During his 1922/1926 mandate, nominal value of Yugoslav currency have a period of stabilisation and even positive growth leaded to a monetary balance. In his mandate as prime minister, Stojadinović reduced state regulation in financial matters. Nearly all of currency transfer abandoned "black" market and was streamed into banking system. Measures taken by the Ministry of Finance produced good results which helped the growth of the foreign trade and export, and even the financial potentials of the peasentry, largest part of the Yugoslav population started to rise. Period between 1936-1937 was in financial way most succesfull years in Kingdom of Yugoslavia history. 